\title{
The evolution of fetal membranes and placentation in carnivores and ungulates (Ferungulata)
}

\author{
Anthony M. Carter ${ }^{1,3}$, Andrea M. Mess ${ }^{2}$ \\ ${ }^{1}$ Cardiovascular and Renal Research, Institute of Molecular Medicine, University of Southern Denmark, Odense, Denmark. \\ ${ }^{2}$ Department of Surgery, School of Veterinary Medicine and Animal Science, University of Sao Paulo, Sao Paulo, SP, Brazil.
}

\begin{abstract}
Molecular phylogenetics has made a substantial contribution to our understanding of the relationships between mammalian orders and has generated trees that can be used to examine the evolution of anatomical and physiological traits. We here summarize findings on fetal membranes and placentation in Ferungulata, a clade comprising carnivores, pangolins, and even- and odd-toed ungulates. Their early ontogeny shows several conserved traits such as superficial attachment of the blastocyst, amnion formation by folding, a large allantoic sac and a temporary yolk sac placenta. In contrast, several characters of the chorioallantoic placenta are derived, including the diffuse and cotyledonary placental types in ungulates and zonary placenta in carnivores, specializations of the interhaemal barrier, the presence of areolae or haemophagous regions and lack of stromal decidual cells. Ungulates produce large amounts of placental proteins including placental lactogens and pregnancy-associated glycoproteins. Evolutionary innovations of the placental system may contribute to the high diversity of lifestyles within Ferungulata and be linked to the evolution of highly precocial offspring in ungulates.
\end{abstract}

Keywords: areolae, Carnivora, Cetartiodactyla, chorioallantoic placenta, decidua, Eutheria, evolution, interhaemal barrier, Perissodactyla, phylogenetic systematics, Placentalia, trophoblast, yolk sac.

\section{Introduction}

Molecular phylogenetics and phylogenomics have given us a good understanding of the relationships between various orders of mammal and the sequence in which those orders evolved (Meredith et al., 2011). With the mammalian tree as a guide, it becomes meaningful to examine the evolution of anatomical and physiological traits. Several studies have done this for the placenta, reaching the conclusion that epitheliochorial placentation is a derived trait and not, as had been supposed, a primitive one (Vogel, 2005; Mess and Carter, 2006; Wildman et al., 2006; Elliot and Crespi, 2009). There have been relatively few studies of other aspects of gestation such as blastocyst attachment and fetal membrane development. This will be a focus of the present paper, which reviews results obtained by plotting characters on the mammalian tree (Mess and Carter, 2006) or by integrating them in a grand analysis of molecular and morphological data (O'Leary et al.,
2013). Metabolic and endocrine functions of the placenta have not been the subject of a rigid phylogenetic analysis. However, there are some interesting innovations in Ferungulata that deserve mention.

\section{The mammalian tree}

Most mammals of interest to veterinarians are part of a clade with a common ancestor referred to as Ferungulata (Fig. 1). There are two sister groups within this clade (Beck et al., 2006; Hou et al., 2009). The first comprises the pangolins (Pholidota) and carnivores (Carnivora). The other encompasses cetaceans plus even-toed ungulates (Cetartiodactyla) and odd-toed ungulates (Perissodactyla). Inclusion of whales and dolphins with the even-toed ungulates is a relatively new development, but well supported by molecular and fossil data (Spaulding et al., 2009).

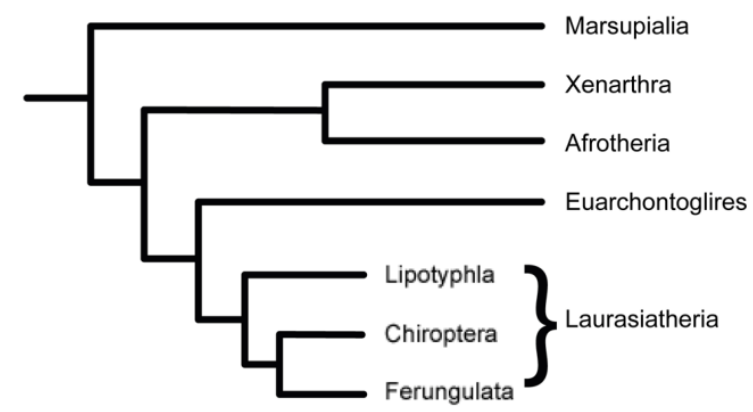

Figure 1. Simplified mammalian tree shows the four major superordinal clades and the position of Ferungulata within Laurasiatheria. Tree topology follows Douady et al. (2002) as used for our analysis of the evolution of fetal membrane and placental characters (Mess and Carter, 2006).

Radiation of the placentals gave rise to four superorders named Laurasiatheria, Euarchontoglires, Afrotheria and Xenarthra (Meredith et al., 2011). Ferungulata is placed in Laurasiatheria together with bats (Chiroptera) and hedgehogs, shrews and moles (Lipotyphla), although not all studies support separating Ferungulata from Chiroptera (Meredith et al., 2011; O'Leary et al., 2013). Some of the orders once included in Ferungulata (Simpson, 1945) are now part of Afrotheria; these include the aardvark, elephants, sirenians and hyraxes.

To describe evolution of reproductive characters in a broader sense, we shall refer to them as conserved (plesiomorphic) or derived (apomorphic) character conditions (Hennig, 1966) compared to the 
most recent common ancestor of crown placentals, i.e. living species and their ancestors (Placentalia; McKenna and Bell, 1997). Following the practice recommended by other authors, we shall refer, rather less accurately, to the common ancestor of eutherians.

\section{Fetal membranes}

Phylogenetically, the yolk sac is the oldest of the fetal membranes. Amnion, allantois and chorion appeared with the cleidoic egg of reptiles, a major step in vertebrate evolution (Ferner and Mess, 2011). All of these membranes can participate in placentation (Starck, 1959; Mossman, 1987; Wooding and Burton, 2008). The fetal membranes of the sea otter (Fig. 2A; Sinha and Mossman, 1966) illustrate the point. The outermost membrane is the trophoblast of the chorion. Early in gestation the yolk sac and chorion form a choriovitelline placenta. Later the allantoic sac expands and together with chorion forms a chorioallantoic placenta. There is in addition an exocoelom lined by extraembryonic mesoderm and, where it abuts the uterus, by chorion. The figure denotes a transitional phase in carnivores; the yolk sac is later displaced from the chorion due to expansion of the exocoelom and allantoic sac.

This scheme is applicable throughout Ferungulata, although with minor variations; the ruminant yolk sac, for example, does not form a choriovitelline placenta. As has recently been reviewed (Carter, 2015; Carter and Enders, 2016), development of the fetal membranes proceeds quite differently in other mammals, including human and mouse.
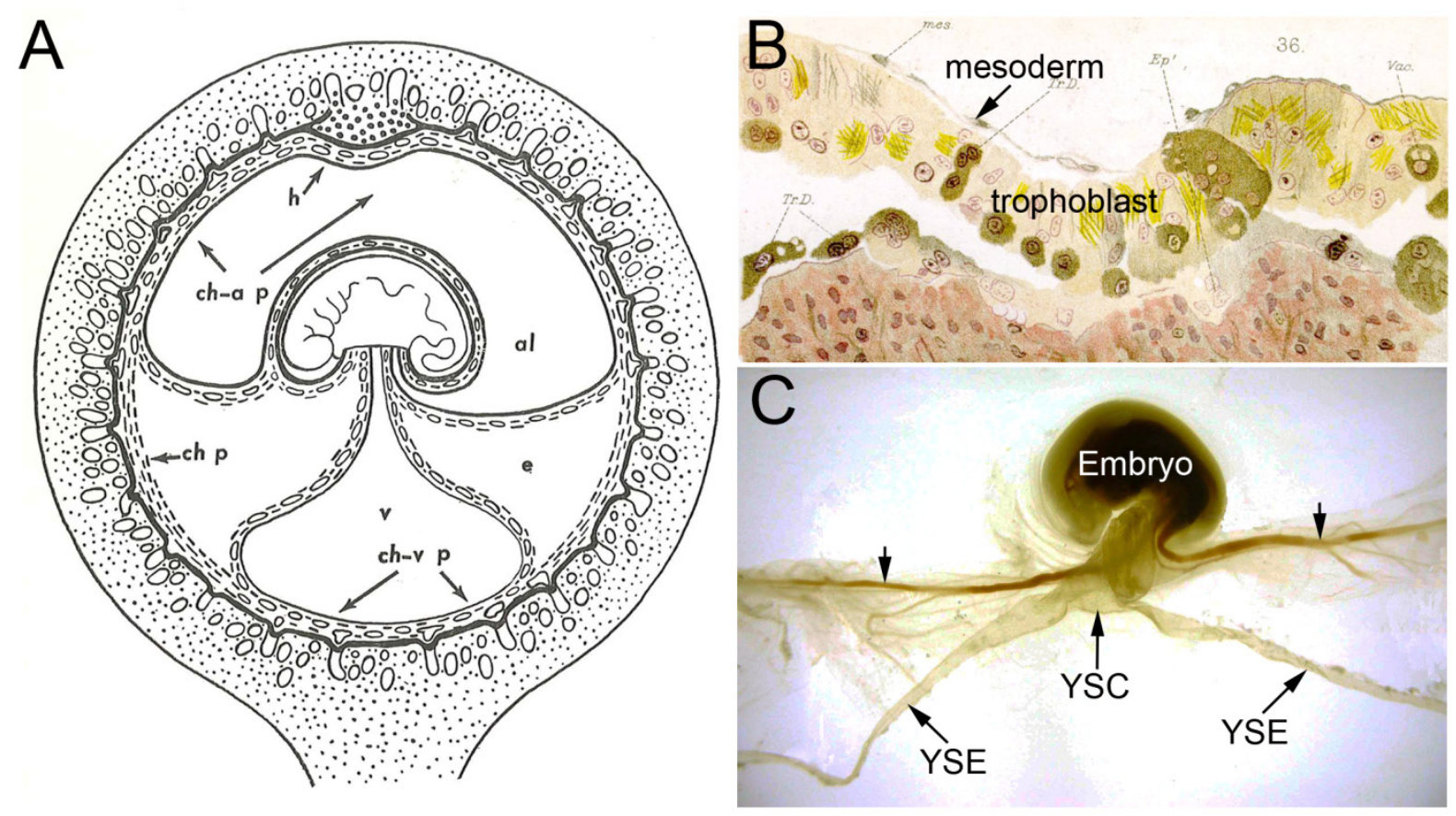

Figure 2. Fetal membranes during early development of a carnivore and a ruminant. A. Membranes of the sea otter (Enhydra lutis) during the transition from choriovitelline (ch-v p) to chorioallantoic (ch-a p) placentation; note the paraplacental chorion (ch p). Reprinted with permission from Sinha and Mossman (1966). B. Pre-implantation blastocyst of the sheep (Ovis aries); at 20 days gestation. The trophoblast is lined throughout by extra-embryonic mesoderm and the yolk sac is no longer attached. Reprinted from Assheton (1906). C. The bovine yolk sac at 20 days of gestation comprises a central portion (YSC) and two extended arms (YSE); allantoic vessels (arrows) are seen extending from the embryo. Courtesy of Dr. Antonio Assis Neto.

\section{Implantation}

An early event in gestation is attachment of the blastocyst to the uterine wall. In most mammals this occurs at the antimesometrial surface. As shown in Fig. $3 \mathrm{~A}$, there was a change in the lineage of Ferungulata and Chiroptera to initial attachment on the mesometrial side (Mess and Carter, 2006). Interestingly, this was reversed in the lineage of carnivores and pangolins, but conserved in the ungulate lineage.

Of greater significance for subsequent development of the membranes is whether the blastocyst remains superficially attached or becomes enclosed in the endometrium either during nidation or subsequently (primary and secondary interstitial implantation). Three studies have now shown that superficial attachment is the conserved or plesiomorphic state of eutherian mammals (Mess and Carter, 2006; O'Leary et al., 2013; McGowen et al., 2014). This state is present in all members of Ferungulata studied to date, whereas interstitial implantation occurs in higher primates and many rodents. 


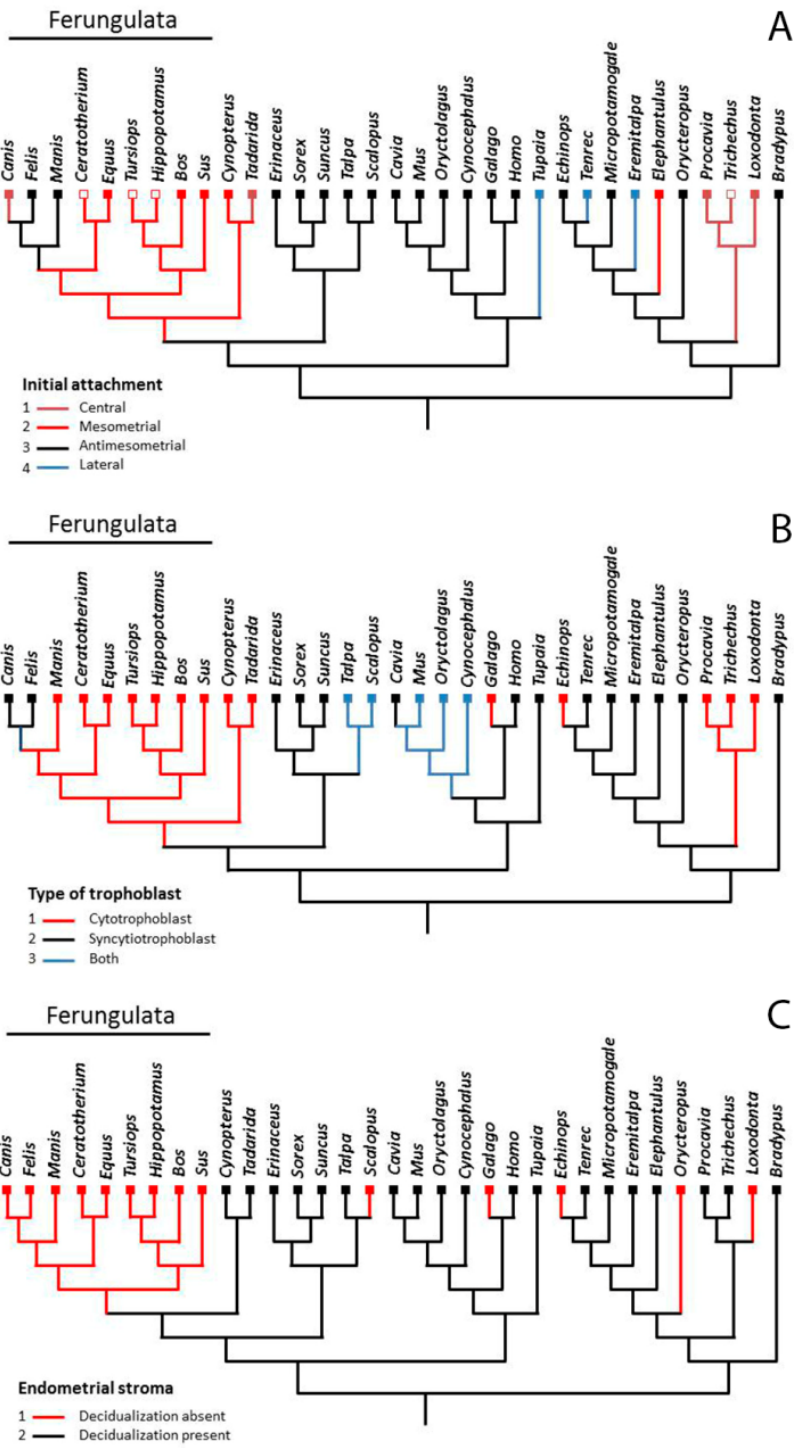

Figure 3. Evolution of implantation and placentation in eutherian mammals. In these phylogenetic trees, Carnivora is represented by dog (Canis) and cat (Felis); Pholidota by a pangolin (Manis); Perissodactyla by rhinoceros (Ceratotherium) and horse (Equus); and Cetartiodactyla by bottlenose dolphin (Tursiops), hippopotamus (Hippopotamus), cow (Bos) and pig (Sus). A. Initial attachment of the blastocyst. The conserved or plesiomorphic condition for eutherians was implantation at the antimesometrial surface of the uterus. This changed to mesometrial implantation in the common lineage of Ferungulata and Chiroptera [represented by a fruit bat (Cynopterus) and a free-tailed bat (Tadarida)]. B. Type of trophoblast in the interhaemal barrier at term. The plesiomorphic condition for eutherians was a layer of syncytiotrophoblast. This changed to cytotrophoblast in the common lineage of Ferungulata and Chiroptera. There was a reversal in the carnivore lineage. $\mathrm{C}$. Endometrial stroma. The plesiomorphic condition for eutherians was decidualization of the endometrium. This was lost in the lineage of Ferungulata, which do not have decidual stroma cells. Data derived from Mess and Carter (2006).

\section{Amniogenesis}

In marsupials and most orders of eutherians, the amnion develops as folds of the extraembryonic somatopleure at the cephalic end and sides of the early embryo. The folds meet and fuse dorsal to the embryo. Several mammals, however, lack amniotic folds or have only rudimentary ones. In the rhesus monkey (Enders et al., 1986) and human (Shahbazi et al., 2016), the amnion forms by cavitation as a space appears amidst a group of polarized cells in the epiblast. In the mouse, a proamnion appears in the centre of the epiblast, but the true amnion is formed from the amniochorionic fold (Dobreva et al., 2010). However, all members of Ferungulata retain the plesiomorphic state, which is amnion formation by folding (Mess and Carter, 2006).

\section{Yolk sac and choriovitelline placentation}

The blastocyst cavity is converted to a primary yolk sac when extraembryonic endoderm (the hypoblast) spreads around the inside of the trophectoderm. Subsequently, during expansion of the exocoelom and allantois, the endoderm is partly or wholly detached and becomes lined by extraembryonic mesoderm. Where it remains in contact with trophoblast as a two-layered structure it is referred to as the bilaminar omphalopleure. Despite lacking blood vessels, the bilaminar omphalopleure serves as a major route for absorption of uterine secretions in, for example, marsupials (Padykula and Taylor, 1982) and the pre-implantation horse embryo (Allen, 2001). Where the attached yolk sac is supplied with mesoderm, generally with vitelline blood vessels, it is referred to as a trilaminar omphalopleure. Development of a trilaminar omphalopleure at some stage of gestation is regarded as plesiomorphic, i.e. it most likely was present in the common ancestor of eutherians (O'Leary et al., 2013) as well as that of Ferungulata (Mess and Carter, 2006). A choriovitelline placenta is present when the vascular part of the yolk sac is in contact with the trophoblast (Fig. 2A).

Although the choriovitelline placenta is transitional in carnivores, the yolk sac persists after detachment from the trophoblast and is found as a Tshaped structure right up to term (Lee et al., 1983; 
Miglino et al., 2006). In pangolin there is likewise a prominent choriovitelline placenta early in gestation that later is displaced by the expanding allantois and subsequently dwindles (De Lange, 1933).

During the first three weeks of equine pregnancy, the conceptus develops within an acellular capsule. At this time the non-vascular part of the yolk sac (bilaminar omphalopleure) plays an essential role in the absorption of nutrients derived from uterine gland secretions (Allen, 2001; Waelchli and Betteridge, 2013). Following dissolution of the capsule, tufts of trophoblast emanating from the non-vascular yolk sac protrude into the mouths of the endometrial glands (Allen, 2001). There is, however, a short-lived vascular portion (trilaminar omphalopleure) that forms a choriovitelline placenta (Enders and Liu, 1991; Allen, 2001). The region between the regressing yolk sac and developing allantois is the site at which the chorionic girdle forms.

There is some variation in Cetartiodactyla. In the pig, the yolk sac rapidly loses contact with the trophoblast, but the detached yolk sac persists within the exocoelom through the first third of gestation (Heuser, 1927). The endoderm forms cell columns and these cells have abundant rough endoplasmic reticulum as well as large mitochondria, suggesting their main function is protein synthesis (Tiedemann and Minuth, 1980). In contrast, in ruminants, the vascular yolk sac does not make contact with the trophoblast (Fig. 2B), but remains in the exocoelom as a free floating structure with two extended arms (Fig. 2C; Assheton, 1906; Russe et al., 1992; Assis Neto et al., 2010). The situation in ruminants is comparable to that in bats, where the yolk sac can form a gland-like structure (Carter and Mess, 2008). Similarly, a free-floating yolk sac is found in human and other higher primates, but as a rule it disappears later in gestation (Enders and King, 1993).

Finally rodents, lagomorphs (e.g. rabbits), colugos and most insectivores undergo a process of yolk sac inversion. Where this is complete it results in the endoderm facing the uterine cavity. The inverted yolk sac of rodents is an important conduit for histotrophe and maternal-fetal transfer of antibodies (King and Enders, 1993; Carter, 2015).

\section{Allantois}

The size of the allantoic sac varies across mammals, but a medium to large allantoic sac is plesiomorphic and conserved in all members of Ferungulata. In contrast, the allantoic sac is absent in higher primates and many rodents, the connection between embryo and chorioallantoic placenta being supplied by an allantoic stalk (Carter et al., 2015).

\section{Amniotic and allantoic fluids}

The volume of fluid in the fetal membranes is substantial. In cattle at 225 days gestation, for example, there are about 2.5 liters of amniotic and 6-9 liters of allantoic fluid (Bongso and Basrur, 1976). The origin and function of these fluids is not fully known despite comprehensive studies in swine (Goldstein et al., 1980), cattle (Wintour et al., 1986) and sheep (Wintour et al., 1994; Gilbert, 1999). Most of the water is acquired through maternal-fetal transfer with only a minor contribution from water produced during fetal oxidative metabolism (Meschia, 1955). Fetal urine drains to the allantoic sac through the urachus and from about midgestation to the amniotic sac via the urethra. There is a further contribution to amniotic fluid of fetal lung liquid. Amniotic fluid is swallowed by the fetus and absorbed from the gastrointestinal tract. In steady state, these processes represent recirculation of fluid. Quite a substantial volume of urine is secreted; about $400 \mathrm{ml}$ to each compartment in sheep (Gilbert, 1999). Maintenance of constant volumes can be explained only by uptake to the fetal vessels of the amniochorion and chorioallantois, known as the intramembranous pathway (Gilbert, 1999). This may be mediated by aquaporin 9, a water channel that is expressed in amniotic and allantoic epithelia, but not in the chorion or placentomes (Wang et al., 2005).

The composition of amniotic and allantoic fluids differs substantially from that of the fetal urine and this can be explained only by the rapid movement of solutes in and out of these fluids presumably via the intramembranous pathway (Gilbert, 1999).

In reptiles as well as mammals, the amnion provides a fluid environment for embryonic development. The function of the allantoic sac is less well understood (Wintour et al., 1994). In species with epitheliochorial placentation, initial expansion of the allantoic fluid may be an important mechanism for bringing the the chorioallantois in contact with the uterine epithelium as suggested by Bazer and colleagues (Goldstein et al., 1980). In addition amniotic and allantoic fluids may act as nutrient reservoirs (Goldstein et al., 1980).

\section{Chorioallantoic placenta}

There is considerable variation among mammals in the shape, internal structure (interdigitation) and interhaemal barrier of the placenta (Carter and Enders, 2004; Wooding and Burton, 2008; Chavatte-Palmer and Tarrade, 2016). In all three respects members of Ferungulata deviate from what is thought to be the conserved state in eutherians.

\section{Placental shape}

Diffuse placentation, where there is extensive contact between the chorioallantoic membrane and uterine wall, is found in pangolins, perissodactyls and most members of Cetartiodactyla including cetaceans, hippopotamus, pigs, peccaries and camels. Equids differ somewhat in possessing microcotyledons. Among ruminants, chevrotains also have diffuse placentation, whereas pecorans have a varying number of placentomes (Klisch and Mess, 2007). All carnivores have zonary placentation (Miglino et al., 2006).

The conserved state of eutherians is the discoid placenta (Mess and Carter, 2006; Wildman et al., 2006; Elliot and Crespi, 2009) as familiar from human and 
mouse. This shape does not occur among Ferungulata. Diffuse placentation likely emerged in the common ancestor of Ferungulata with zonary placentation representing a further evolutionary step in the lineage of carnivores.

\section{Interdigitation}

Interdigitation between fetal villi and maternal trabeculae is usually associated with diffuse placentation. It reaches greater complexity in cotyledonary placentas (Hradecky et al., 1988; Klisch and Mess, 2007) and zonary placentas (Capellini, 2012). In higher primates the fetal villi do not interdigitate with maternal trabeculae but are surrounded by maternal blood. The third type of interdigitation, the placental labyrinth, is plesiomorphic and is conserved, for example, in rodents and lagomorphs (Mess and Carter, 2006; Wildman et al., 2006; Elliot and Crespi, 2009).

\section{Interhaemal barrier}

Consideration of the tissue layers separating fetal and maternal blood suggests three principal types of interhaemal barrier. In epitheliochorial placentation, the uterine epithelium remains largely intact (Carter and Enders, 2013). This type occurs throughout Ferungulata with the exception of carnivores. Otherwise it is seen only in strepsirrhine primates (lemurs and lorises). For pecoran ruminants, where uterine epithelial cells undergo fusion with binucleate trophoblast cells (see below), the term synepitheliochorial is sometimes preferred (Wooding and Burton, 2008).

In endotheliochorial placentation, the trophoblast is in contact with the maternal capillary endothelium, which often is hypertrophied (Enders and Carter, 2012b). This type of interhaemal barrier occurs in all carnivores with the exception of hyaenas. Finally, in haemochorial placentas the trophoblast is directly in contact with the maternal blood (Enders and Carter, 2012a). Among Ferungulata this has been observed only in hyaenas (Enders et al., 2006). Endotheliochorial and haemochorial states are together referred to as invasive placentation (Carter and Pijnenborg, 2010; Carter et al., 2015).

Vogel was the first to show the epitheliochorial condition is a derived type (Vogel, 2005). That has been confirmed numerous times though there is disagreement about whether the plesiomorphic state is endotheliochorial (Mess and Carter, 2006; Martin, 2008) or haemochorial (Wildman et al., 2006; Elliot and Crespi, 2009).

\section{Trophoblast of the placental barrier}

Placentas differ as to whether the trophoblast present in the interhaemal barrier at term is syncytiotrophoblast, cytotrophoblast (cellular) or both (Fig. 3B). Our analysis (Mess and Carter, 2006) suggests that the common ancestor of eutherians had just syncytiotrophoblast. This is of interest in the context of placental evolution as the propensity for trophoblast cells to fuse and form multinucleate masses is linked to the expression of syncytins. They are the product of endogenous retroviral envelope genes, which have been acquired independently in several lineages (Dupressoir et al., 2012). Because syncytiotrophoblast often accomplishes the initial penetration of the uterine epithelium, it has even been suggested that capture of a retroviral gene was an essential first step in the evolution of placentation (Lavialle et al., 2013).

As Fig. 3B suggests, replacement of syncytiotrophoblast by cytotrophoblast occurred in the common ancestor of Ferungulata and Chiroptera. There were, however, subsequent reversals. The first occurred in the lineage of ruminants. A remarkable feature of their placenta is the ability of a binucleate trophoblast cell to fuse with a uterine epithelial cell to form a hybrid that either is a trinucleate cell as in the cow or a syncytium as in the sheep or the chevrotain (Wooding, 1992; Klisch et al., 1999; Wooding et al., 2007). Tellingly, ruminants have captured a retroviral envelope gene (Syncytin-Rum 1) and binucleate cells thereby express a syncytin that is able to promote cell fusion in vitro (Cornelis et al., 2013). There is evidence of an additional but similar gene in bovines (Nakaya et al., 2013).

The second exception is in carnivores, where there is an apparent reversal towards the presence of syncytiotrophoblast in the barrier (Fig. 3B). Carnivores have captured a syncytin gene (Syncytin-Carl) that is expressed in the placenta of dog and cat (Cornelis et al., 2012). This gene is conserved throughout Carnivora with evidence for purifying selection and conservation of fusogenic activity. It does not occur in the pangolins (Pholidota), which retain the epitheliochorial state (Cornelis et al., 2012).

\section{Areolae and haemophagous organs}

Columnar trophoblast cells, polarized with their endocytic and lysosomal systems oriented for ingestion, are widespread among mammals. Generally this trophoblast is heterophagous, ingesting uterine secretions, cellular debris or maternal erythrocytes (Enders and Carter, 2006). Histotrophic nutrition assumes greater importance where placentation is epitheliochorial, since haemotrophic nutrition is constrained by the absence of direct access by trophoblast to maternal blood. It is particularly important to have alternate routes for fetal acquisition of iron and copper (McArdle et al., 2008; Carter, 2012).

Two types of adaptation occur in ungulates. The first is the areola, in which columnar trophoblast is arranged above gland openings. In pig (Renegar et al., 1982) and horse (Fig. 4A; Wooding et al., 2000), endometrial glands secrete the iron-rich glycoprotein uteroferrin, which is taken up by the polarized trophoblast of the areolae. Recently, uptake of uteroferrin was also described in the water buffalo (Bubalus bubalis; Pereira et al., 2009). Although the uteroferrin gene (tartrate-resistant acid phosphatase type 5 ) is found in other mammals, its central role in fetal iron supply likely emerged in the ungulate lineage. In sheep and other ruminants (Burton et al., 1976; Burton, 
1982), there are, in addition, haemophagous regions designed to ingest maternal erythrocytes and extract iron from the haemoglobin (Fig. 4B).

Similar adaptations occur in carnivores. Thus, the polar zone of the chorioallantois of the cat exhibits pinocytotic activity (Leiser and Enders, 1980a), whilst the remainder of the paraplacenta is haemophagous (Leiser and Enders, 1980b). A prominent haemophagous organ occupies a central, antimesometrial position in the sea otter and other mustelids, in skunks, and in raccoons and allies (reviewed in Carter and Enders, 2016); these three families share a common ancestor (Eizirik et al., 2010). Even the haemochorial placenta of hyaenas has haemophagous areas (Fig. 4C). According to De Lange, the pangolin placenta lacks specializations such as areolae (De Lange, 1933). There is copious uterine gland secretion, however, and columnar trophoblast similar in appearance to areolar trophoblast (Fig. 4D; Enders and Carter, 2006).
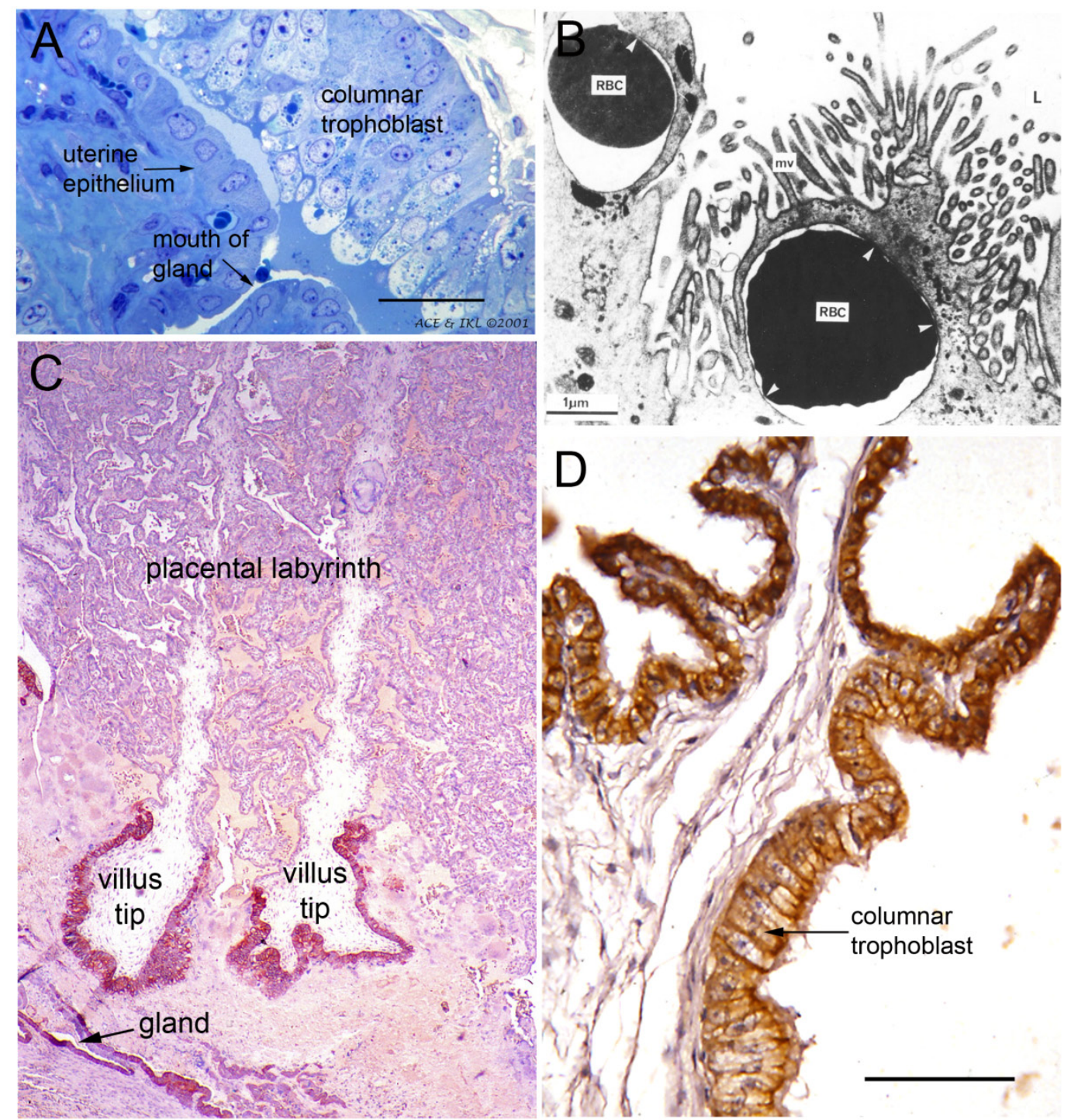

Figure 4. Columnar trophoblast is found in most placentas of carnivores and ungulates. A. Areola of the horse (Equus caballus) at 47 days of gestation. Note the columnar trophoblast above the opening of a uterine gland. Reprinted with permission from Carter and Enders (Carter and Enders, 2013). B. Haemophagous region of the cotyledon from a sheep (Ovis aries) at 98 days gestation. Two red blood cells (RBC) are enclosed within vacuoles in the apical cytoplasm of columnar trophoblast cells. Scale bar: $1 \mu \mathrm{m}$. Reproduced with permission from Burton et al. (1976). C. Intraplacental haemophagous region of a spotted hyaena (Crocuta crocuta). The columnar trophoblast at the tip of the villus stains for cytokeratin and is heterophagous. The uterine glands below also stain for cytokeratin. Reprinted with permission from Carter and Enders (2016). D. Fetal villus of a pangolin (Manis sp.) with trophoblast stained for cytokeratin. Note the columnar trophoblast cells. The trophoblast has pulled away from the endometrial folds (not in field). Reprinted with permission from Enders and Carter (2006).

\section{Decidua}

There has been interest of late in the evolution of uterine responses to pregnancy, particularly the differentiation of endometrial stromal fibroblasts into decidual stromal cells. We had found that a decidua was 
present in the eutherian common ancestor, but was lost in the lineage of Ferungulata (Fig. 3C; Mess and Carter, 2006). Recent studies support the view that evolution of decidua occurred in the eutherian stem lineage coincidental with the appearance of invasive placentation (Wagner et al., 2014; Chavan et al., 2016). It was possible to define a set of transcription factor interactions that were needed to regulate decidual gene expression (Wagner et al., 2014). Moreover, by analyzing the literature and reviewing archival material, this group came to the conclusion that decidua formation was important in the peri-implantation period; they gave several examples, including armadillo and tenrec, where decidual stromal cells were lost later in gestation. It was suggested that the acquisition of additional endocrine and immune functions by decidual stromal cells, including a role in pregnancy maintenance, first occurred in the lineage of Euarchontoglires (Chavan et al., 2016).

Significantly, their analysis proposed a limited role for decidual stroma cells in laurasiatherian species outside Ferungulata, notably the European mole (Talpa europaea), the false vampire bat (Megaderma lyra) and the disc-winged bat (Thyroptera tricolor; Chavan et al., 2016). The short-lived function of decidua in these orders (Chiroptera and Lipotyphla) was seen to be part of the maternal response to invasive placentation. In this light the disappearance of stromal decidual cells in Ferungulata could be linked to the evolution of noninvasive placentation.

\section{Metabolic and endocrine functions of the placenta}

Sugar metabolism

Fructose occurs at high concentrations in the fetal plasma of ruminants, pigs, whales (Cetartiodactyla) and horses (Perissodactyla), but not that of dog, cat or ferret (Carnivora) or any other mammal (Goodwin, 1956). Experiments in sheep (Alexander et al., 1955) and pig (White et al., 1979) have established that a substantial amount of glucose is converted to fructose in the placenta. In a porcine trophectoderm cell line, Bazer and colleagues (Kim et al., 2012) could show that fructose stimulates cell proliferation by activation of the MTOR signalling pathway and synthesis of hyaluronic acid through the hexosamine metabolic pathway. Placenta does not utilize fructose as a primary source of metabolic energy, but it is possible that the fetus metabolizes fructose through the pentose shunt (Bazer et al., 2014). Either way it is clear that placental conversion of glucose to fructose arose in the ungulate lineage.

\section{Placental protein and peptide hormones}

Placenta-specific hormones arise through gene duplication (Table 1). Convergent evolution may occur as in the emergence of chorionic gonadotrophins by duplication of the gene for the $\beta$-subunit of luteinizing hormone, which happened in the lineages of equids and anthropoid primates (Carter, 2012). Equine chorionic gonadotropin is secreted by the trophoblast of the endometrial cups (Wooding et al., 2001) and acts as a luteotrophic factor. Another example of a peptide that maintains corpus luteum function is interferon- tau (IFN$\tau)$, which arose through duplication of the IFN-omega gene (Roberts et al., 2003). In pecoran ruminants, IFN- $\tau$ is secreted by the trophectoderm of the blastocyst and acts by binding to receptors in the endometrium and suppressing pulsatile secretion of the luteolytic factor prostaglandin F2 $\alpha$ (Fleming et al., 2006).

Table 1. Evolution of placental protein and peptide hormones in ungulates and carnivores.

\begin{tabular}{|c|c|c|c|}
\hline Hormone & Derivation & Distribution & Remarks \\
\hline $\begin{array}{l}\text { Equine chorionic } \\
\text { gonadotropin (eCG) }\end{array}$ & $\begin{array}{l}\text { Luteinizing hormone } \beta \text { - } \\
\text { subunit }\end{array}$ & Equids & \\
\hline Interferon- $\tau$ (IFNT) & Interferon- $\omega$ (IFNW) & Pecoran ruminants & \\
\hline $\begin{array}{l}\text { Placental lactogens and } \\
\text { prolactin-like proteins }\end{array}$ & Prolactin (PRL) & All ruminants & \\
\hline Placental growth hormone & Growth hormone $(\mathrm{GH})$ & Sheep and goat & \\
\hline $\begin{array}{l}\text { Pregnancy-associated } \\
\text { glycoproteins (PAGs) }\end{array}$ & An aspartic proteinase & Cetartiodactyla. & $\begin{array}{l}\text { Ancient and recent genes, } \\
\text { the latter from a second } \\
\text { round of gene duplication in } \\
\text { ruminants }\end{array}$ \\
\hline $\begin{array}{l}\text { Pregnancy-specific } \\
\text { glycoproteins (PSGs) }\end{array}$ & $\begin{array}{l}\text { Carcinoembryonic antigen } \\
\text { cell adhesion molecule } \\
\text { (CEACAM) family }\end{array}$ & Five in the horse & \\
\hline Relaxin-like factor & Relaxin & $\begin{array}{l}\text { Described in the } \\
\text { dog }\end{array}$ & $\begin{array}{l}\text { Expressed in genital tract } \\
\text { and placenta }\end{array}$ \\
\hline
\end{tabular}

The placental lactogens and prolactin-like proteins of ruminants have arisen by tandem duplication of the prolactin gene (PRL). While some ruminants have a single placental lactogen, cattle have as many as 13 PRL-like genes (Ushizawa et al., 2007). Ovine placental lactogen (oPL) binds both to growth hormone $(\mathrm{GH})$ and PRL receptors in the uterine glands thereby stimulating gland hyperplasia and secretion of histotrophe (Noel et al., 2003). There is sequential action on the glands of IFN- $\tau$, oPL and ovine placental GH (Noel et al., 2003). Placental lactogen may play a subsidiary role in corpus luteum maintenance (Buttle, 1978).

Placental expression of pregnancy-associated 
glycoproteins (PAGs) occurs throughout Cetartiodactyla (Wallace et al., 2015). As with placental lactogens, the number of $P A G$ genes varies and is highest in cattle (Telugu et al., 2009). PAGs belong to a wider family of aspartic proteinases and have undergone two rounds of gene duplication. The "ancient" PAGs retain the active site. In pig and cow they are expressed at the microvillous junction between uterine epithelium and trophoblast (Wooding et al., 2005). They may function as linking molecules and contribute to fetal-maternal anchorage. The second round of duplication occurred in ruminants and many of the resultant proteins lack the active site. They are expressed mainly at the surface of binucleate cells and have been ascribed immunomodulatory functions (Wooding et al., 2005; Wallace et al., 2015). A PAG-like gene has been characterized in equids (horse and mountain zebra, Equus zebra), where it is expressed in the trophectoderm of the blastocyst, including girdle cells, and trophoblast of the term placenta (Xie et al., 1997; Green et al., 1999). The promotor of equine PAG resembles that of a bovine PAG gene (Green et al., 1999). A related protein has been cloned from the cat (Green et al., 1999; Hughes et al., 2003), but its expression pattern is unknown. The equine and feline variants are not glycosylated, however, and are now referred to as pepsin-F (Wallace et al., 2015). It is thought that PAGs proper evolved in the Cetartiodactyla lineage and were derived from an ancestral pepsin-F gene that in turn originated from the pepsin-A gene (Wallace et al., 2015).

Pregnancy-specific glycoproteins (PSGs) are placental hormones found in primates and rodents, where they appear to be associated with invasive placentation (Carter, 2012). They are not found in dogs or cattle, yet seven PSG-like genes have now been identified in the horse (Kammerer and Zimmermann, 2010; Aleksic et al., 2016). Five of them are expressed in trophoblast, notably in the invasive trophoblast of the chorionic girdle and endometrial cups (Aleksic et al., 2016). Evolution of these placental proteins in the horse has been linked conceptually to the transition from a non-invasive epitheliochorial placenta to one with an invasive component in the shape of girdle cells (Kammerer and Zimmermann, 2010; Aleksic et al., 2016). Work currently in progress should clarify whether equine PSGs exert immunomodulatory properties similar to those of rodents and primates. If so this is a remarkable instance of convergent evolution.

In contrast to the ungulates, placental peptide hormones do not play a prominent role in carnivores, where reproductive endocrinology is best understood for the dog (Kowalewski, 2012). There is a canine relaxinlike factor expressed in the male and female reproductive tracts and by trophoblast (Klonisch et al., 2001). No information is available about placental hormones in pangolins.

\section{Placental evolution}

The early development and fetal membranes of ungulates, carnivores and pangolins (Ferungulata) presents an interesting mix of conserved and derived characters. Conserved traits include superficial implantation, amniogenesis by folding, formation of a temporary choriovitelline placenta and retention of a large allantoic sac. There is one derived character, initial implantation at the mesometrial rather than antimesometrial side, for which we have no interpretation.

The placenta of ungulates and pangolins exhibits many derived characters, including its shape, mode of interdigitation and interhaemal barrier. Perhaps linked to this suite of characters is the absence of decidua formation (Chavan et al., 2016). Reversals occur mainly among the carnivores, especially with respect to the interhaemal barrier, which is endotheliochorial in most carnivores and haemochorial in hyaenas.

Ungulates in particular are large mammals with long gestation periods and give birth to a single or few well-developed (precocial) young. These are also derived traits as the ancestral mammal is thought to have been small, had a short gestation period, large litters and poorly developed (altricial) neonates (O'Leary et al., 2013). The change in reproductive strategy necessarily implies heavy maternal investment in each pregnancy. As discussed in greater detail elsewhere (Carter and Enders, 2013), the evolution of epitheliochorial placentation may have been driven by the need to prime the immune system to combat uterine infection rather, as in more invasive placentation, to suppress immune responses in favour of allowing trophoblast invasion. Analogous reasoning has been presented elsewhere (Moffett and Loke, 2006), and the the epitheliochorial placenta compared to a commensal residing in the gut. Certainly there is a resemblance to gut in that a large number of intraepithelial lymphocytes can be observed in the uterus of horse and ruminants (Enders and Liu, 1991; Lee et al., 1997; Fox and Meeusen, 1999; Fox et al., 2010).

There was a major reversal in the lineage of carnivores towards shorter gestations, larger litters and more altricial neonates. It is feasible that this change in strategy placed different constraints on the immune system allowing return to a more invasive placental type.

\section{The mammalian tree is a work in progress}

There remain uncertainties about the order of branching of the mammalian tree. The ancestor of placental mammals emerged in the Cretaceous, but there was rapid diversification close to the CretaceousPalaeogene boundary when mammals occupied ecospaces vacated through extinction of the non-avian dinosaurs (O'Leary et al., 2013; Phillips, 2016). Because even the major clades emerged within a short time span, it has proven difficult to root the mammalian tree (Nishihara et al., 2009; Dos et al., 2012). Much evidence favours the configuration in the tree we used for our analysis (Douady et al., 2002), where Afrotheria and Xenarthra are sister taxa and sister to all other 
mammals (Waters et al., 2007; Meredith et al., 2011; Dos et al., 2012), but there are dissenting views (Beck et al., 2006; McCormack et al., 2012). In respect of the character states found in the eutherian common ancestor, our findings are in general agreement with the analyses of O'Leary et al., although they placed Xenarthra near the root of the tree (O'Leary et al., 2013).

There is also some disagreement about the relation between Chiroptera and Ferungulata as well as the branch order within the latter clade Nishihara et al., 2006; Nery et al., 2012), but analyses of retroposed elements (Kriegs et al., 2006) and phylogenomic data (Hou et al., 2009) support the configuration on which our analysis is based. Some character transformations occur in the common ancestor of Ferungulata and Chiroptera and our interpretation would not be affected by a difference in branch order. All major studies on placentation have assumed Ferungulata (Mess and Carter, 2006; Wildman et al., 2006; Elliot and Crespi, 2009), but placental characters would be less easy to resolve if Chiroptera were included in the mix, as there is great variation even among the families of bats (Carter and Mess, 2008).

\section{Conclusion}

The eutherian taxon Ferungulata, which is well supported by molecular phylogenies, comprises clades with very diverse lifestyles such as large ungulates, carnivores and pangolins. Nevertheless, they share important traits of early ontogeny and fetal membrane development that have been conserved from the most recent common ancestor of extant eutherians. In contrast, their placentation is characterized by derived conditions. In ungulates, for instance, evolution of their precocial reproductive strategy is associated with the establishment of an epitheliochorial placenta and loss of decidual stromal cells. Although carnivores have reverted to the altricial reproductive strategy of the common ancestor of extant eutherians, they likewise possess features of placentation that represent derived conditions within the group, i.e. a zonary placenta with syncytial trophoblast in the barrier. Thus, evolutionary innovations of the placental system have contributed to the diversity of lifestyles within Ferungulata Understanding the evolution of this system allows better comprehension of its plasticity. It may help to address problems associated with implantation or endometrial dysfunction in production animals and wild species.

\section{Conflict of interest statement}

The authors declare that they have no conflicting interests.

\section{References}

Aleksic D, Blaschke L, Missbach S, Hanske J, Weiss W, Handler J, Zimmermann W, Cabrera-Sharp V, Read JE, de Mestre AM, O'Riordan R, Moore T, Kammerer R. 2016. Convergent evolution of pregnancy-specific glycoproteins in human and horse.
Reproduction, 152:171-184.

Alexander DP, Huggett AS, Nixon DA, Widdas WF. 1955. The placental transfer of sugars in the sheep: the influence of concentration gradient upon the rates of hexose formation as shown in umbilical perfusion of the placenta. J Physiol, 129:367-383.

Allen WR. 2001. Fetomaternal interactions and influences during equine pregnancy. Reproduction, 121:513-527.

Assheton R. 1906. The morphology of the ungulate placenta, particularly the development of that organ in the sheep, and notes upon the placenta of the elephant and hyrax. Phil Trans R Soc Lond B Biol Sci, 198:143-220.

Assis Neto AC, Pereira FT, Santos TC, Ambrosio CE, Leiser R, Miglino MA. 2010. Morpho-physical recording of bovine conceptus (Bos indicus) and placenta from days 20 to 70 of pregnancy. Reprod Domest Anim, 45:760-772.

Bazer FW, Wu G, Johnson GA, Wang X. 2014. Environmental factors affecting pregnancy: endocrine disrupters, nutrients and metabolic pathways. Mol Cell Endocrinol, 398:53-68.

Beck RM, Bininda-Emonds OR, Cardillo M, Liu FG, Purvis A. 2006. A higher-level MRP supertree of placental mammals. BMC Evol Biol, 6:93.

Bongso TA, Basrur PK. 1976. Foetal fluids in cattle. Can Vet J, 17:38-41.

Burton GJ, Samuel CA, Steven DH. 1976. Ultrastructural studies of the placenta of the ewe: phagocytosis of erythrocytes by the chorionic epithelium at the central depression of the cotyledon. $Q J \operatorname{Exp}$. Physiol Cogn Med Sci, 61:275-286.

Burton GJ. 1982. Review article. Placental uptake of maternal erythrocytes: a comparative study. Placenta, 3:407-434.

Buttle HL. 1978. The maintenance of pregnancy in hypophysectomized goats. J Reprod Fertil, 52:255-260.

Capellini I. 2012. The evolutionary significance of placental interdigitation in mammalian reproduction: contributions from comparative studies. Placenta, 33:763-768.

Carter AM, Enders AC. 2004. Comparative aspects of trophoblast development and placentation. Reprod Biol Endocrinol, 2:46.

Carter AM, Mess A. 2008. Evolution of the placenta and associated reproductive characters in bats. $J$ Exp Zool B Mol Dev Evol, 310:428-449.

Carter AM, Pijnenborg R. 2010. Evolution of invasive placentation with special reference to non-human primates. Best Pract Res Clin Obstet Gynaecol, 25:249257.

Carter AM. 2012. Evolution of placental function in mammals: the molecular basis of gas and nutrient transfer, hormone secretion, and immune responses. Physiol Rev, 92:1543-1576.

Carter AM, Enders, AC. 2013. The evolution of epitheliochorial placentation. Annu Rev Anim Biosci, 1:443-467.

Carter AM. 2015. IFPA Senior Award Lecture: Mammalian fetal membranes. Placenta. doi: 10.1016/j.placenta.2015.10.012.

Carter AM, Enders AC, Pijnenborg R. 2015. The role 
of invasive trophoblast in implantation and placentation of primates. Philos Trans $R$ Soc Lond B Biol Sci, 370:20140070.

Carter AM, Enders AC. 2016. Placentation in mammals: definitive placenta, yolk sac, and paraplacenta. Theriogenology, 86:278-287.

Chavan AR, Bhullar BA, Wagner GP. 2016. What was the ancestral function of decidual stromal cells? A model for the evolution of eutherian pregnancy. Placenta, 40:40-51.

Chavatte-Palmer P, Tarrade A. 2016. Placentation in different mammalian species. Ann Endocrinol (Paris), 77:67-74.

Cornelis G, Heidmann O, Bernard-Stoecklin S, Reynaud K, Veron G, Mulot B, Dupressoir A, Heidmann T. 2012. Ancestral capture of syncytin-Car1, a fusogenic endogenous retroviral envelope gene involved in placentation and conserved in Carnivora. Proc Natl Acad Sci USA, 109:E432-E441.

Cornelis G, Heidmann O, Degrelle SA, Vernochet C, Lavialle C, Letzelter C, Bernard-Stoecklin S, Hassanin A, Mulot B, Guillomot M, Hue I, Heidmann T, Dupressoir, A. 2013. Captured retroviral envelope syncytin gene associated with the unique placental structure of higher ruminants. Proc Natl Acad Sci USA, 110:E828-E837.

De Lange D. 1933. Plazentarbildung. In: Bolk L, Göppert E, Kallius E, Lubosch W. (Ed.). Handbuch vergleichenden Anatomie Wirbeltiere. Berlin: Urban \& Schwarzenberg. pp. 155-234.

Dobreva MP, Pereira PN, Deprest J, Zwijsen A. 2010 On the origin of amniotic stem cells: of mice and men. Int J Dev Biol, 54:761-777.

Dos RM, Inoue J, Hasegawa M, Asher RJ, Donoghue PC, Yang Z. 2012. Phylogenomic datasets provide both precision and accuracy in estimating the timescale of placental mammal phylogeny. Proc Biol Sci, 279:34913500 .

Douady CJ, Chatelier PI, Madsen O, de Jong WW, Catzeflis F, Springer MS, Stanhope MJ. 2002 Molecular phylogenetic evidence confirming the Eulipotyphla concept and in support of hedgehogs as the sister group to shrews. Mol Phylogenet Evol, 25:200-209. Dupressoir A, Lavialle C, Heidmann T. 2012. From ancestral infectious retroviruses to bona fide cellular genes: role of the captured syncytins in placentation. Placenta, 33:663-671

Eizirik E, Murphy WJ, Koepfli KP, Johnson WE, Dragoo JW, Wayne RK, O'Brien SJ. 2010. Pattern and timing of diversification of the mammalian order Carnivora inferred from multiple nuclear gene sequences. Mol Phylogenet Evol, 56:49-63.

Elliot MG, Crespi BJ. 2009. Phylogenetic evidence for early hemochorial placentation in eutheria. Placenta, 30:949-967.

Enders AC, Schlafke S, Hendrickx AG. 1986. Differentiation of the embryonic disc, amnion, and yolk sac in the rhesus monkey. Am J Anat, 177:161-185.

Enders AC, Liu IK. 1991. Trophoblast-uterine interactions during equine chorionic girdle cell maturation, migration, and transformation. Am J Anat, 192:366-381.
Enders AC, King BF. 1993. Development of the human yolk sac. In: Nogales FF (Ed.). The Human Yolk Sac and Yolk Sac Tumors. Berlin; Springer-Verlag. pp. 33-47.

Enders AC, Blankenship TN, Conley AJ, Jones CJ. 2006. Structure of the midterm placenta of the spotted hyena, Crocuta crocuta, with emphasis on the diverse hemophagous regions. Cells Tissues Organs, 183:141155.

Enders AC, Carter AM. 2006. Comparative placentation: some interesting modifications for histotrophic nutrition - a review. Placenta, 27(suppl. A):S11-S16.

Enders AC, Carter AM. 2012a. Review: The evolving placenta: different developmental paths to a hemochorial relationship. Placenta, 33(suppl):S92-S98

Enders AC, Carter AM. 2012b. The evolving placenta: convergent evolution of variations in the endotheliochorial relationship. Placenta, 33:319-326.

Ferner K, Mess A. 2011. Evolution and development of fetal membranes and placentation in amniote vertebrates. Respir Physiol Neurobiol, 178:39-50.

Fleming JG, Spencer TE, Safe SH, Bazer FW. 2006. Estrogen regulates transcription of the ovine oxytocin receptor gene through GC-rich SP1 promoter elements. Endocrinology, 147:899-911.

Fox A, Meeusen E. 1999. Sheep perforin: identification and expression by gammadelta $\mathrm{T}$ cells from pregnant sheep uterine epithelium. Vet Immunol Immunopathol, 68:293-296.

Fox A, Maddox JF, de Veer MJ, Meeusen EN. 2010. GammadeltaTCR + cells of the pregnant ovine uterus express variable $\mathrm{T}$ cell receptors and contain granulysin. $J$ Reprod Immunol, 84:52-56.

Gilbert WM. 1999. Allantoic fluid compositional changes during acute urine drainage in fetal sheep. $J$ Soc Gynecol Investig, 6:17-21.

Goldstein MH, Bazer FW, Barron DH. 1980. Characterization of changes in volume, osmolarity and electrolyte composition of porcine fetal fluids during gestation. Biol Reprod, 22:1168-1180.

Goodwin RF. 1956. Division of the common mammals into two groups according to the concentration of fructose in the blood of the foetus. J Physiol, 132:146-156.

Green JA, Xie S, Szafranska B, Gan X, Newman AG, McDowell K, Roberts RM. 1999. Identification of a new aspartic proteinase expressed by the outer chorionic cell layer of the equine placenta. Biol Reprod, 60:10691077.

Hennig W. 1966. Phylogenetic Systematics. Urbana, IL: University of Illinois Press.

Heuser CH. 1927. A study of the implantation of the ovum of the pig from the stage of the bilaminar blastocyst to the completion of the fetal membranes. Contrib Embryol Carnegie Inst, 19:229-243.

Hou ZC, Romero R, Wildman DE. 2009. Phylogeny of the Ferungulata (Mammalia: Laurasiatheria) as determined from phylogenomic data. Mol Phylogenet Evol, 52:660-664.

Hradecky P, Mossman H.W, Stott GG. 1988. Comparative histology of antelope placentomes. Theriogenology, 29:693-714.

Hughes AL, Green JA, Piontkivska H, Roberts RM. 
2003. Aspartic proteinase phylogeny and the origin of pregnancy-associated glycoproteins. Mol Biol Evol, 20:1940-1945.

Kammerer R, Zimmermann W. 2010. Coevolution of activating and inhibitory receptors within mammalian carcinoembryonic antigen families. BMC Biol, 8:12.

Kim J, Song G, Wu G, Bazer FW. 2012. Functional roles of fructose. Proc Natl Acad Sci, USA, 109:E1619E1628.

King BF, Enders AC. 1993. Comparative development of the mammalian yolk sac. In: Nogales FF (Ed.). The Human Yolk Sac and Yolk Sac Tumors. Berlin: SpringerVerlag. pp. 1-32.

Klisch K, Pfarrer C, Schuler G, Hoffmann B, Leiser R. 1999. Tripolar acytokinetic mitosis and formation of feto-maternal syncytia in the bovine placentome: different modes of the generation of multinuclear cells. Anat Embryol (Berlin), 200:229-237.

Klisch K, Mess A. 2007. Evolutionary differentiation of Cetartiodactyl placentae in the light of the viviparitydriven conflict hypothesis. Placenta, 28:353-360.

Klonisch T, Kauffold J, Steger K, Bergmann M, Leiser R, Fischer B, Hombach-Klonisch S. 2001. Canine relaxin-like factor: unique molecular structure and differential expression within reproductive tissues of the dog. Biol Reprod, 64:442-450.

Kowalewski MP. 2012. Endocrine and molecular control of luteal and placental function in dogs: a review. Reprod Domest Anim, 47(suppl. 6):19-24.

Kriegs JO, Churakov G, Kiefmann M, Jordan U, Brosius J, Schmitz J. 2006. Retroposed elements as archives for the evolutionary history of placental mammals. PLoS Biol, 4:e91.

Lavialle C, Cornelis G, Dupressoir A, Esnault C, Heidmann O, Vernochet C, Heidmann T. 2013. Paleovirology of 'syncytins', retroviral env genes exapted for a role in placentation. Philos Trans R Soc Lond B Biol Sci, 368:20120507.

Lee CS, Wooding FB, Morgan G. 1997. Quantitative analysis throughout pregnancy of intraepithelial large granular and non-granular lymphocyte distributions in the synepitheliochorial placenta of the cow. Placenta, 18:675-681.

Lee SY, Anderson JW, Scott GL, Mossman HW. 1983. Ultrastructure of the placenta and fetal membranes of the dog: II. The yolk sac. Am J Anat, 166:313-327.

Leiser R, Enders AC. 1980a. Light- and electronmicroscopic study of the near-term paraplacenta of the domestic cat. I. Polar zone and paraplacental junctional areas. Acta Anat (Basel), 106:293-311.

Leiser R, Enders AC. 1980b. Light- and electronmicroscopic study of the near-term paraplacenta of the domestic cat. II. Paraplacental hematoma. Acta Anat (Basel), 106:312-326.

Martin RD. 2008. Evolution of placentation in primates: Implications of mammalian phylogeny. Evol Biol, 35:125-145.

McArdle HJ, Andersen HS, Jones H, Gambling L. 2008. Copper and iron transport across the placenta: regulation and interactions. J. Neuroendocrinol, 20:427431.

McCormack JE, Faircloth BC, Crawford NG,
Gowaty PA, Brumfield RT, Glenn TC. 2012. Ultraconserved elements are novel phylogenomic markers that resolve placental mammal phylogeny when combined with species-tree analysis. Genome Res, 22:746-754.

McGowen MR, Erez O, Romero R, Wildman DE. 2014. The evolution of embryo implantation. Int $J$ Dev Biol, 58:155-161.

McKenna MC, Bell SK. 1997. Classification of Mammals above the Species Level. New York, NY: Columbia University Press.

Meredith RW, Janecka JE, Gatesy J, Ryder OA, Fisher CA, Teeling EC, Goodbla A, Eizirik E, Simao TL, Stadler T, Rabosky DL, Honeycutt RL, Flynn JJ, Ingram CM, Steiner, C, Williams TL, Robinson TJ, Burk-Herrick A, Westerman M, Ayoub NA, Springer MS, Murphy WJ. 2011. Impacts of the cretaceous terrestrial revolution and $\mathrm{KPg}$ extinction on mammal diversification. Science, 334:521-524.

Meschia G. 1955. Colloidal osmotic pressures of fetal and maternal plasmas of sheep and goats. Am J Physiol, 181:1-8.

Mess A, Carter AM. 2006. Evolutionary transformations of fetal membrane characters in Eutheria with special reference to Afrotheria. J Exp Zool B Mol Dev Evol, 306:140-163.

Miglino MA, Ambrosio CE, dos Santos MD, Wenceslau CV, Pfarrer C, Leiser R. 2006. The carnivore pregnancy: the development of the embryo and fetal membranes. Theriogenology, 66:1699-1702.

Moffett A, Loke C. 2006. Immunology of placentation in eutherian mammals. Nat Rev Immunol, 6:584-594.

Mossman HW. 1987. Vertebrate Fetal Membranes. New Brunswick, NJ: Rutgers University Press.

Nakaya Y, Koshi K, Nakagawa S, Hashizume K, Miyazawa T. 2013. Fematrin-1 is involved in fetomaternal cell-to-cell fusion in Bovinae placenta and has contributed to diversity of ruminant placentation. $J$ Virol, 87:10563-10572.

Nery MF, Gonzalez DJ, Hoffmann FG, Opazo JC. 2012. Resolution of the laurasiatherian phylogeny: evidence from genomic data. Mol Phylogenet Evol, 64:685-689.

Nishihara H, Hasegawa M, Okada N. 2006. Pegasoferae, an unexpected mammalian clade revealed by tracking ancient retroposon insertions. Proc Natl Acad Sci USA, 103:9929-9934

Nishihara H, Maruyama S, Okada N. 2009. Retroposon analysis and recent geological data suggest near-simultaneous divergence of the three superorders of mammals. Proc Natl Acad Sci USA, 106:5235-5240.

Noel S, Herman A, Johnson GA, Gray CA, Stewart MD, Bazer FW, Gertler A, Spencer TE. 2003. Ovine placental lactogen specifically binds to endometrial glands of the ovine uterus. Biol Reprod, 68:772-780.

O'Leary MA, Bloch JI, Flynn JJ, Gaudin TJ, Giallombardo A, Giannini NP, Goldberg SL, Kraatz BP, Luo ZX, Meng J, Ni X, Novacek MJ, Perini FA, Randall ZS, Rougier GW, Sargis EJ, Silcox MT, Simmons NB, Spaulding M, Velazco PM, Weksler M, Wible JR, Cirranello AL. 2013. The placental mammal ancestor and the post-K-Pg radiation of placentals. 
Science, 339:662-667.

Padykula HA, Taylor JM. 1982. Marsupial placentation and its evolutionary significance. J Reprod Fertil Suppl, 31:95-104

Pereira FT, Braga FC, Burioli KC, Kfoury Jr JR, Oliveira L, Papa P, Carvalho AF, Ambrosio CE, Bazer FW, Miglino MA. 2009. Transplacental transfer of iron in the Water Buffalo (Bubalus bubalis): uteroferrin and erythrophagocytosis. Reprod Domest Anim, 45:907-914

Phillips MJ. 2016. Geomolecular dating and the origin of placental mammals. Syst Biol, 65:546-557.

Renegar RH, Bazer FW, Roberts RM. 1982. Placental transport and distribution of uteroferrin in the fetal pig. Biol Reprod, 27:1247-1260.

Roberts RM, Ezashi T, Rosenfeld CS, Ealy AD, Kubisch HM. 2003. Evolution of the interferon tau genes and their promoters, and maternal-trophoblast interactions in control of their expression. Reproduction Suppl, 61:239-251.

Russe I, Sinowatz F, Richter L, Lehmann M, Schallenberger E. 1992. Die Entwicklung des Dottersackes beim Wiederkäuer (Schaf und Rind). Anat Histol Embryol, 21:324-347.

Shahbazi MN, Jedrusik A, Vuoristo S, Recher G, Hupalowska A, Bolton V, Fogarty NM, Campbell A, Devito LG, Ilic D, Khalaf Y, Niakan KK, Fishel S, Zernicka-Goetz M. 2016. Self-organization of the human embryo in the absence of maternal tissues. Nat Cell Biol, 18:700-708.

Simpson GG. 1945. The principles of classification and a classification of mammals. Bull Am Mus Nat Hist, 85:1350 .

Sinha AA, Mossman HW. 1966. Placentation of the sea otter. Am J Anat, 119:521-553.

Spaulding M, O'Leary MA, Gatesy J. 2009. Relationships of Cetacea (Artiodactyla) among mammals: increased taxon sampling alters interpretations of key fossils and character evolution. PLoS One, 4:e7062.

Starck D. 1959. Ontogenie und Entwicklungsphysiologie der Säugetiere. In: Helmcke JG, Lengerken H, Starck D. (Ed.). Handbuch der Zooologie. Berlin: Walter de Gruyter. pp. 128-276.

Telugu BP, Walker AM, Green JA. 2009. Characterization of the bovine pregnancy-associated glycoprotein gene family--analysis of gene sequences, regulatory regions within the promoter and expression of selected genes. BMC Genomics, 10:185.

Tiedemann K, Minuth WW. 1980. The pig yolk sac I. Fine structure of the posthaematopoietic organ. Histochemistry, 68:133-146.

Ushizawa K, Takahashi T, Hosoe M, Ohkoshi K, Hashizume K. 2007. Expression and characterization of novel ovine orthologs of bovine placental prolactinrelated proteins. BMC Mol Biol, 8:95.

Vogel P. 2005. The current molecular phylogeny of Eutherian mammals challenges previous interpretations of placental evolution. Placenta, 26:591-596.
Waelchli RO, Betteridge KJ. 2013. Morphology of twin and triplet equine conceptuses during weeks 3 and 4 of pregnancy. Reprod Fertil Dev, 25:762-774.

Wagner GP, Kin K, Muglia L, Pavlicev M. 2014. Evolution of mammalian pregnancy and the origin of the decidual stromal cell. Int J Dev Biol, 58:117-126.

Wallace RM, Pohler KG, Smith MF, Green JA. 2015. Placental PAGs: gene origins, expression patterns, and use as markers of pregnancy. Reproduction, 149:R115R126.

Wang S, Chen J, Huang B, Ross MG. 2005. Cloning and cellular expression of aquaporin 9 in ovine fetal membranes. Am J Obstet Gynecol, 193:841-848.

Waters PD, Dobigny G, Waddell PJ, Robinson TJ. 2007. Evolutionary history of LINE-1 in the major clades of placental mammals. PLoS One, 2:e158.

White CE, Piper EL, Noland PR. 1979. Conversion of glucose to fructose in the fetal pig. J Anim Sci, 48:585590.

Wildman DE, Chen C, Erez O, Grossman LI, Goodman M, Romero R. 2006. Evolution of the mammalian placenta revealed by phylogenetic analysis. Proc Natl Acad Sci USA, 103:3203-3208.

Wintour EM, Laurence BM, Lingwood BE. 1986. Anatomy, physiology and pathology of the amniotic and allantoic compartments in the sheep and cow. Aust Vet $J$, 63:216-221.

Wintour EM, Alcorn D, McFarlane A, Moritz, K, Potocnik SJ, Tangalakis K. 1994. Effect of maternal glucocorticoid treatment on fetal fluids in sheep at 0.4 gestation. Am J Physiol, 266:R1174-R1181.

Wooding FB. 1992. Current topic: the synepitheliochorial placenta of ruminants: binucleate cell fusions and hormone production. Placenta 13:101-113.

Wooding FB, Morgan G, Fowden AL, Allen WR. 2000. Separate sites and mechanisms for placental transport of calcium, iron and glucose in the equine placenta. Placenta, 21:635-645.

Wooding FB, Morgan G, Fowden AL, Allen WR. 2001. A structural and immunological study of chorionic gonadotrophin production by equine trophoblast girdle and cup cells. Placenta, 22:749-767.

Wooding FB, Roberts RM, Green JA. 2005. Light and electron microscope immunocytochemical studies of the distribution of pregnancy associated glycoproteins (PAGs) throughout pregnancy in the cow: possible functional implications. Placenta, 26:807-827.

Wooding FB, Kimura J, Fukuta K, Forhead AJ. 2007. A light and electron microscopical study of the Tragulid (mouse deer) placenta. Placenta, 28:1039-1048.

Wooding FB, Burton GJ. 2008. Comparative Placentation: Structures, Function and Evolution. Berlin: Springer-Verlag.

Xie S, Green J, Bixby JB, Szafranska B, DeMartini JC, Hecht S, Roberts RM. 1997. The diversity and evolutionary relationships of the pregnancy-associated glycoproteins, an aspartic proteinase subfamily consisting of many trophoblast-expressed genes. Proc Natl Acad Sci USA, 94:12809-12816. 